\title{
EFFECT OF ACID CITRATE DEXTROSE DURING PLATELETPHERESIS ON FIRST- TIME HEALTHY DONORS: BETWEEN SAFETY AND TOXICITY
}

\author{
Samah, A. El-Nagdy1, Yara, M. El-Fakharany ${ }^{1}$ \\ ${ }^{1}$ Department of Forensic Medicine and Clinical Toxicology Faculty of medicine, Zagazig University, \\ EGYPT
}

\begin{abstract}
Introduction: During apheresis, anticoagulation is accomplished by use of acid citrate dextrose (ACD). Acid citrate dextrose returns to the donor with the remainder of blood after separation of the targeted blood component. Objectives: This study was conducted to assess the potential toxic effects of ACD in first-time blood donors through clinical and biochemical assessment. Methodology: Seventy -five healthy plateletpheresis donors were recruited in the study where they were subjected to clinical and laboratory assessment just before the procedure (baseline), at $30 \mathrm{~min}$. \& at $60 \mathrm{~min}$. during the procedure and $30 \mathrm{~min}$. post procedure. Clinical evaluation included vital signs evaluation and reporting of any clinical manifestation developed. Biochemical assessment included $\mathrm{ABG}$, serum ionized $\mathrm{Ca}(\mathrm{iCa})$, ionized $\mathrm{Mg}(\mathrm{iMg})$ and parathyroid hormone $(\mathrm{PTH})$ levels. Also activity of erythrocyte phosphofructokinase (PFK) and hematological parameters including RBCs (million/ul), hemoglobin level ( $\mathrm{Hb} \mathrm{g} / \mathrm{dl}$ ) and hematocrite (Hct \%) were evaluated. Results: Apheresis using citrate anticoagulant resulted in changes in mineral homeostasis in the form of hypocalcemia and hypomagnesemia with subsequent tremors $(9.3 \%)$ and tetany $(5.3 \%)$. Also, some of the donors exhibited tachycardia and hypotension. Parathyroid hormone (PTH) level increased during apheresis which nearly returned to normal level 30 min. after the procedure while, no significant changes in ABG were detected at different time intervals of the procedure. When RBCs PFK activity was measured, a significant decrease was found during the procedure with significant decrease in RBCs at 60 min. and post $30 \mathrm{~min}$. But no significant changes were detected as regard $\mathrm{Hb}$ level and $\mathrm{Hct} \%$ in comparison to baseline ones. Conclusion: Citrate toxicity may occur even with first time exposure in platelet apheresis donors in form of possible developing tremors, tetany, tachycardia and hypotension with decreased calcium \& magnesium levels, increased PTH, decreased erythrocyte PFK activity with subsequent decreased RBCs integrity and possible hemolysis.
\end{abstract}

Key words: Citrate toxicity, plateletpheresis, first-time donors, PFK activity.

\section{INTRODUCTION}

R lood donation used to be considered a 1 safe procedure with low risk. However, in the last few decades, some hazards were developed during donation. So, more strict precautions are now required during donation procedure (Monika and Tarun, 2014)

Apheresis is a medical procedure in which blood of a donor is passed through an apparatus to separate out one particular constituent and returns the remainder to the circulation, thus it is an extracorporeal procedure (Mariano, 2017). There are different types of donation including plasmapheresis, erythrocytapheresis, plateletpheresis and leukapheresis (Szczepiorkowski et al., 2010).

The standard anticoagulant utilized during apheresis donation procedure is citrate. The most common citrate solutions used are acid citrate dextrose (ACD-A) which is $3 \%$ citrate and ACD-B which is $2 \%$ 
citrate (Lee and Arepally, 2012). Plasma concentration of citrate in the extracorporeal circuit is maintained at $15-24 \mathrm{mmol} / \mathrm{L}$ to facilitate anticoagulation (Burgstaler, 2006).

Remainder of blood returned to donor will contain citrate (Custer et al., 2012). The amount of citrate returned to the blood donor depends on some factors including; the concentration of citrate anticoagulant in the extracorporeal circuit, the volume of blood returned to the donor, the concentration of citrate within the blood returned to the donor and the rate of blood return to the donor (Burgstaler, 2006).

It was found that some donor developed neuromuscular and cardiac manifestations ranging in severity from mild to severe effects in form of mild dysesthesias (most common) to tetany, seizures or even cardiac arrhythmias (Buchta et al., 2003).

Phosphofructokinase (PFK) is the key and most regulatory enzyme involved in controlling glycolysis. Its activity depends on a large number of metabolites and cofactors with subsequent affection on glycolysis (Wu et al., 2006). Mor et al. (2011) mentioned that ATP and citrate affect activity of PFK and that concentrations of ATP and citrate in the steady state under normal metabolic conditions are apparently sufficient to keep phosphofructokinase-1 relatively inhibited. Hence, it was assumed that exposure of apheresis donors to citrate during apheresis process will affect PFK activity.
Erythrocytes (RBCs) depend solely on anaerobic glycolysis for generation of high energy phosphate required for maintaining the erythrocyte's integrity. So, interruption of this process by inhibition of the involved enzymes including PFK can result in hemolytic anemia (Van Wijk and Van Solinge, 2005).

Taking the above mentioned studies in consideration, it was hypothesized that citrate exposure could cause abnormalities in mineral homeostasis and may affect erythrocyte PFK activity.

So, the aim of this study was to evaluate potential acute toxic effects of ACD during apheresis donation through clinical and biochemical assessment of firsttime donors.

\section{METHODOLOGY}

\section{II.1.Equpiments \&Chemicals:}

The blood collecting system used was Trima Accel Automated (Terumo BCT software, version 6.0; Terumo BCT, Lakewood, Colorado, USA) (Fig.1). During plateletpheresis procedures, the closed system apheresis kits, and anticoagulant ACD-A in the proportion of 1: 10-1: 12 (Fig.1) (blood flow rate $50-80 \mathrm{ml} / \mathrm{min}$ ) were used. The duration of apheresis procedure was from 60 to 90 minutes (Swarup et al., 2009). 


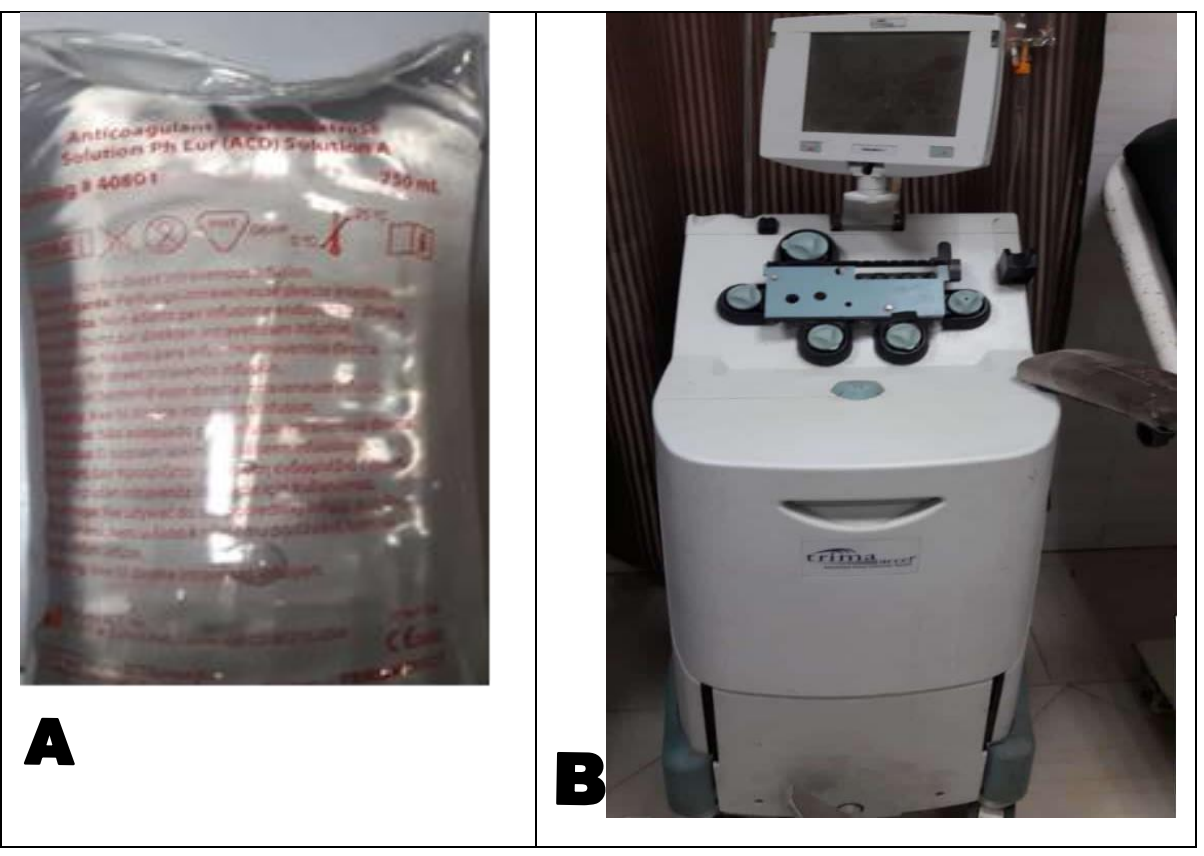

Fig. 1: (A): Acid citrate dextrose A solution used in plateletpheresis procedure. (B): Trima Accel automated blood collecting system used in plateletpheresis.

\section{II.2.Subjects:}

Informed consents were obtained from donors who were informed about purpose of the study, its benefit for the community and possible adverse effects that might happen during or after the procedure.

Seventy-five (75) healthy plateletpheresis donors at Blood Bank of Zagazig University Hospitals were included in this study during the period from July 2017 to March 2018.

\section{-Inclusion criteria:}

Donors for the first time were selected as per the set criteria for single donor platelet (SDP) preparation according to $\mathrm{AABB}$ (the American Association of Blood Banks) guidelines and criteria of National Blood Center (Muhammad et al., 2016) which included the following:

-Age: 18-60 yrs.
-Weight: $\geq 55 \mathrm{~kg}$.

-Hb level: not less than $12.5 \mathrm{~g} / \mathrm{dl}$.

- Platelet count $>150 \times 103 / \mu 1$.

-Negative tests for HIV, Hepatitis B, Hepatitis C, Syphilis and Malaria.

- Absence of any illness.

-No consumption of non-steroidal antiinflammatory drugs for last seven days.

- Adequate sleep before donation $>5$ hours.

- Had taken at least a light meal before donation.

-Execlusion criteria: Donors with history of chronic diseases or receiving medications.

\section{II.3. Methods:}

The included donors were subjected to clinical and biochemical assessment just before the procedure (baseline, $00 \mathrm{~min}$.), 30 
min. and 60 min. during the procedure and 30 min. post-procedure as follows:

II.3.1.Clinical evaluation: Assessment of vital signs (heart rate, systolic blood pressure, diastolic blood pressure and temperature) and recording of any clinical manifestations reported by the donors.

\section{II.3.2.Biochemical assessment:}

It was conducted in Zagazig University Hospital Laboratories. One $\mathrm{mL}$ of arterial blood was used for arterial blood gases (ABG) assessment. Four ml of blood were collected from sterile diversion pouch placed on apheresis circuit from each donor at the different intervals of the study and used as follow:

- Two $\mathrm{ml}$ of blood let to clot and centrifuged for separation of serum, then $\mathrm{iCa}^{++}$and $\mathrm{iMg}^{+}$levels were measured by ion-selective electrode (ISE) method by the AVL 9884 electrolyte analyzer (AVL Scientific, Roswell, Ga) according to Zoppi et al. (1996).

- The other $2 \mathrm{~mL}$ of blood sample were collected in EDTA-containing tubes. Whole blood and aliquots of plasma were used for measuring the following:

-Parathyroid hormone (PTH): Plasma parathyroid hormone levels were measured by enzyme linked immunoassay method (ELISA) by Human PTH ELISA Kit (ab230931) kit purchased from Abcam PLC (UK) (Zheng et al., 2018).

-Hematological parameters: Erythrocytes (RBCs) count (million/ul), $\mathrm{Hb}$ concentration $(\mathrm{g} / \mathrm{dl})$, hematocrit $(\%)$ were measured using a Sysmex KX-21 NTM automated hematology analyzer (Sysmex Europe $\mathrm{GmbH}$ ) (Samuel et al., 2010)

-Erythrocytes Phosphofructokinase (PFK) activity: The method used was colorimetric assay using chemicals supplied by (Sigma Aldrich, St. Louis, MO. USA) as follow; separation of RBC by centrifugation of the sample for $10 \mathrm{~min}$ at $400 \mathrm{xg}$, then washing with normal saline for several times. This was followed by lysis of erythrocytes with the help of sodium phosphate buffer at $\mathrm{PH}$ of 7.4. The method depended on conversion of fructose-6-phosphate and ATP is converted to fructose-1,6diphosphate and ADP by PFK. Adenosine diphosphate (ADP) is then converted into NADH which reduce a colorless agent with the intensity of the colour was measured and was proportional to the activity of PFK (Aniket et al., 2016).

\section{II.3.3.Statistical analysis:}

Data was analyzed using Social Statistical Package version10 (SPSS Inc., Chicago, IL). Quantitative data were summarized as mean \pm standard deviation (X $\pm \mathrm{SD})$. Test of significance for quantitative data was done using Anova test for comparison between groups. Least significant difference (LSD) for multiple comparisons (Norusis, 1997). significance level was considered at $\mathrm{p}$ value $<0.05$.

\section{III.RESULTS}

\section{III.1.Clinical Evaluation:}

Clinical manifestations reported by the subjects at different time intervals of apheresis procedure showed that the most reported manifestations were lightheadedness $(32 \%)$ followed by nausea \& vomiting and shivering $(21.3 \%$ \& $14.6 \%$ respectively). Twitches \& tremors represented $9.3 \%$ of the manifestations reported. Tetany was detected in $5.3 \%$ of the donors during apheresis with no one developed seizures (Fig. 2). 


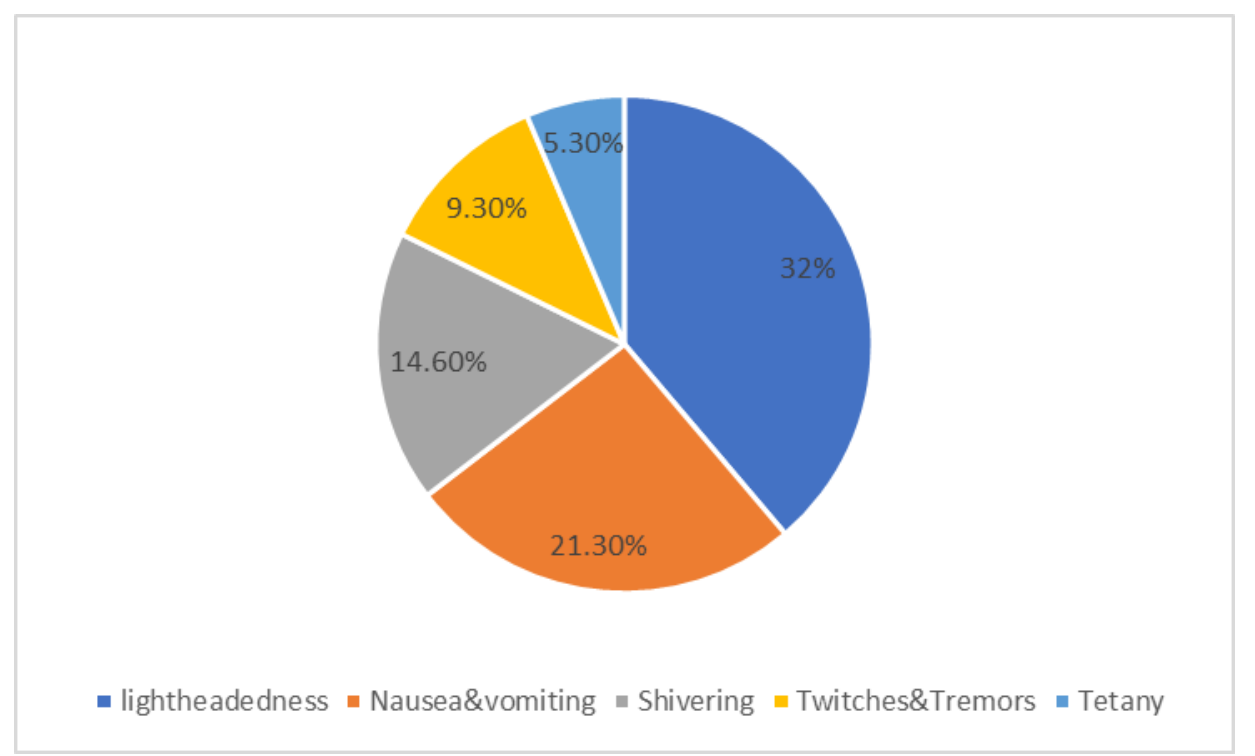

Fig. 2: Percentage of clinical manifestations developed by first time donors during plateletpheresis

Evaluation of vital signs among donors revealed a significant increase of HR assessed at $30 \mathrm{~min}$ and $60 \mathrm{~min}$. of procedure when compared with baseline assessment and that assessed at $30 \mathrm{~min}$. post procedure $(\mathrm{p}<0.05)$. Also, there was a significant decrease in DBP measured at $60 \mathrm{~min}$. of procedure when compared with baseline measurement $(\mathrm{p}<0.05)$. After apheresis, DBP returned to normal and recorded nonsignificant difference with baseline measurement $(\mathrm{p}>0.05)$. Other vital signs (SBS, RR and Temp.) showed nonsignificant difference at different time intervals of the procedure $(p>0.05)$ (Table $1)$.

Table (1): Statistical comparison regarding mean values of vital signs assessed at different time intervals of apheresis among first-time donors using ANOVA and LSD tests:

\begin{tabular}{|c|c|c|c|c|c|c|c|}
\hline \multirow{7}{*}{ 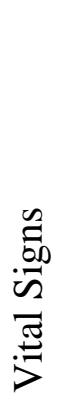 } & & \multicolumn{4}{|c|}{ Time of sampling } & \multicolumn{2}{|c|}{ ANOVA TEST } \\
\hline & & $\begin{array}{l}\text { Pre-procedure } \\
\text { (Baseline) }\end{array}$ & $\begin{array}{l}\text { at min. } 30 \text { of } \\
\text { procedure }\end{array}$ & $\begin{array}{l}\text { at } \min .60 \text { of } \\
\text { procedure }\end{array}$ & $\begin{array}{l}30 \text { min. after } \\
\text { procedure }\end{array}$ & $\mathrm{F}$ & $\mathrm{P}$ \\
\hline & HR & $97.59 \pm 10.30$ & $105.75 \pm 8.36^{\mathrm{a}}$ & $109.52 \pm 10.04^{\mathrm{a}}$ & $100.53 \pm 12.42^{b, c}$ & 19.71 & $0.000 * *$ \\
\hline & SBP & $111.94 \pm 13.15$ & $110.45 \pm 14.95$ & $111.56 \pm 12.73$ & $110.34 \pm 14.32$ & 0.25 & 0.86 \\
\hline & DBP & $69.31 \pm 6.58$ & $67.43 \pm 5.43$ & $65.92 \pm 8.71^{\mathrm{a}}$ & $69.54 \pm 7.33^{c}$ & 4.31 & $0.00 * *$ \\
\hline & RR & $17.43 \pm 2.12$ & $17.51 \pm 1.93$ & $18.21 \pm 1.87$ & $17.65 \pm 2.74$ & 1.93 & 0.12 \\
\hline & Temp. & $37.02 \pm 0.12$ & $37.04 \pm 0.06$ & $37.46 \pm 0.02$ & $37.05 \pm 0.02$ & 1.42 & 0.24 \\
\hline
\end{tabular}

HR: heart rate SBP: systolic blood pressure $\quad$ DBP: diastolic blood pressure $\quad$ RR: respiratory rate $\quad$ Temp: temperature min.: minute F: ANOVA **: Significant $: p<0.05$

LSD for repeated measure ANOVA expressed as letters: a: Significant with (pre-procedure (baseline), b Significant with (at min. 30 of procedure) and c: Significant with (at min. 60 of procedure). 


\section{III.2. Biochemical assessment:}

When ABG was evaluated among donors, no significant difference found at

different time intervals of apheresis $(\mathrm{p}>0.05)$

(Table 2).

Table (2): Statistical comparison regarding mean values of arterial blood gases (ABG) findings in first time donors at different time interval of apheresis procedure using ANOVA and LSD tests

\begin{tabular}{|l|l|l|l|l|l|l|l|}
\hline \multirow{2}{*}{} & \multicolumn{4}{|c|}{ Time of sampling } & \multicolumn{2}{l|}{ ANOVA TEST } \\
\cline { 3 - 8 } & $\begin{array}{l}\text { 00min. } \\
\text { (Baseline) }\end{array}$ & $\begin{array}{l}\text { at min. 30 of } \\
\text { procedure }\end{array}$ & $\begin{array}{l}\text { at min. 60 of } \\
\text { procedure }\end{array}$ & $\begin{array}{l}\text { 30 min. post } \\
\text { procedure }\end{array}$ & $\mathrm{F}$ & $\mathrm{P}$ \\
\cline { 2 - 8 } & $\mathrm{PH}$ & $7.37 \pm 0.08$ & $7.37 \pm 0.09$ & $7.38 \pm 0.18$ & $7.36 \pm 0.12$ & 0.33 & 0.81 \\
\cline { 2 - 8 } \\
\cline { 2 - 8 } & PO2 & $90.62 \pm 5.93$ & $91.94 \pm 6.34$ & $91.82 \pm 6.25$ & $91.04 \pm 5.94$ & 0.80 & 0.49 \\
\cline { 2 - 8 } & PCO2 & $35.72 \pm 6.21$ & $35.94 \pm 4.62$ & $36.03 \pm 5.46$ & $35.69 \pm 5.84$ & 0.07 & 0.98 \\
\cline { 2 - 8 } & HCO3 & $24.02 \pm 3.51$ & $24.93 \pm 4.02$ & $25.21 \pm 3.96$ & $23.68 \pm 4.57$ & 2.43 & 0.06 \\
\hline
\end{tabular}

\section{F: ANOVA}

Measurement of ionized $\mathrm{Ca}$ (iCa) level at different time intervals of apheresis procedure revealed significant decrease at $30 \mathrm{~min}$. and $60 \mathrm{~min}$. of the procedure when compared with baseline value $(\mathrm{p}<0.05)$. At the same time, iCa level increased again after the procedure with no significant difference was found between pre and post procedure values ( $p>0.05$ ) (Table 3, Fig. 3).
$\mathrm{P}>005$ : non significant

Ionized $\mathrm{Mg}$ (iMg) level demonstrated a significant decrease at $60 \mathrm{~min}$. of the procedure when compared with baseline measurement $(\mathrm{p}<0.05)$, then started to increase again after apheresis with no significant difference determined between baseline value and that reported $30 \mathrm{~min}$. after apheresis ( $p>0.05)$ (Table 3, Fig. 4).

Table (3): Statistical comparison regarding mean values of serum ionized calcium (iCa) \& ionized magnesium (iMg) levels in first- time donors at different time intervals of apheresis procedure using ANOVA and LSD tests:

\begin{tabular}{|c|l|l|l|l|l|l|l|}
\hline Time interval & \multicolumn{2}{l|}{ Time of sampling } & \multicolumn{2}{l|}{ ANOVA test } \\
\cline { 2 - 8 } & $\begin{array}{l}\text { Minerals assessed } \\
(\text { Baseline })\end{array}$ & $\begin{array}{l}\text { min. 30 of } \\
\text { procedure }\end{array}$ & $\begin{array}{l}\text { min. 60 of } \\
\text { procedure }\end{array}$ & $\begin{array}{l}30 \text { min. post } \\
\text { procedure }\end{array}$ & $\mathrm{F}$ & $\mathrm{P}$ \\
\hline $\begin{array}{l}\text { Serum ica level } \\
(\mathrm{mEq} / \mathrm{L})\end{array}$ & $2.23 \pm 0.13$ & $2.10 \pm 0.17^{\mathrm{a}}$ & $2.07 \pm 0.25^{\mathrm{a}}$ & $2.19 \pm 0.17^{\mathrm{b}, \mathrm{c}}$ & 10.11 & $0.000^{* *}$ \\
\hline $\begin{array}{l}\text { Serum } \\
(\mathrm{mEq} / \mathrm{L})\end{array}$ & $1.75 \pm 0.53$ & $1.64 \pm 0.61$ & $1.48 \pm 0.49^{\mathrm{a}}$ & $1.71 \pm 0.51^{\mathrm{c}}$ & 3.69 & $0.01^{* *}$ \\
\hline
\end{tabular}

ica: serum ionized calcium

iMg: ionized magnesium

F: ANOVA

**: Significant $(\mathrm{p}<0.05)$. LSD for repeated measure ANOVA expressed as letters: a: Significant with (pre-procedure (Baseline), b Significant with (at min. 30 of procedure) and c: Significant with (at min. 60 of procedure). 


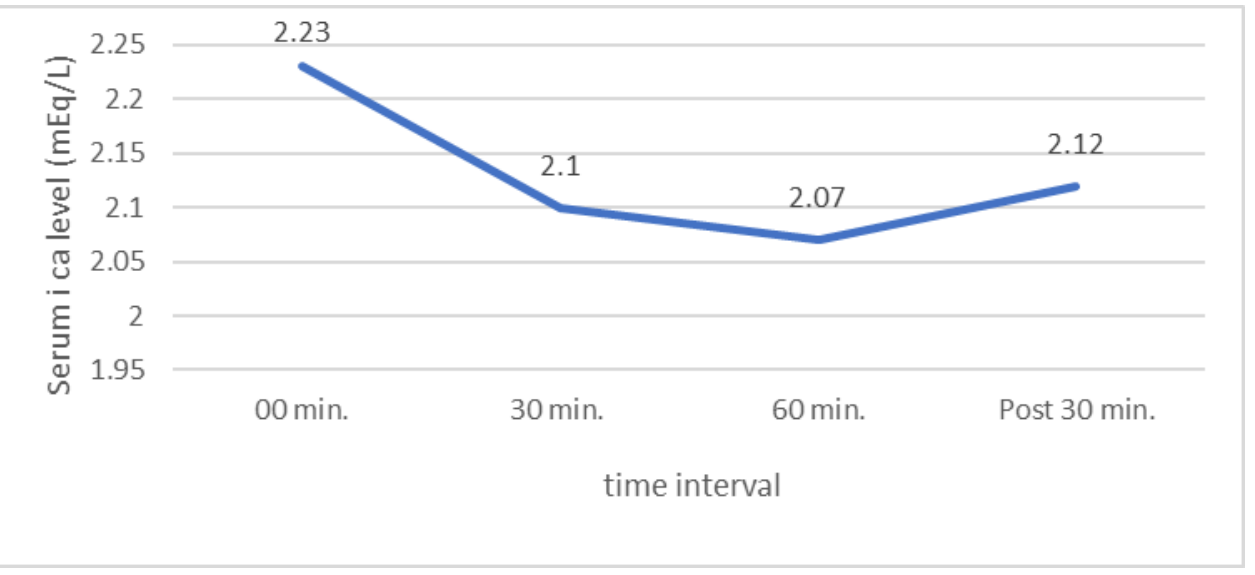

Fig. 3: Mean values of serum ionized calcium iCa level in donors at different time intervals of apheresis procedure.

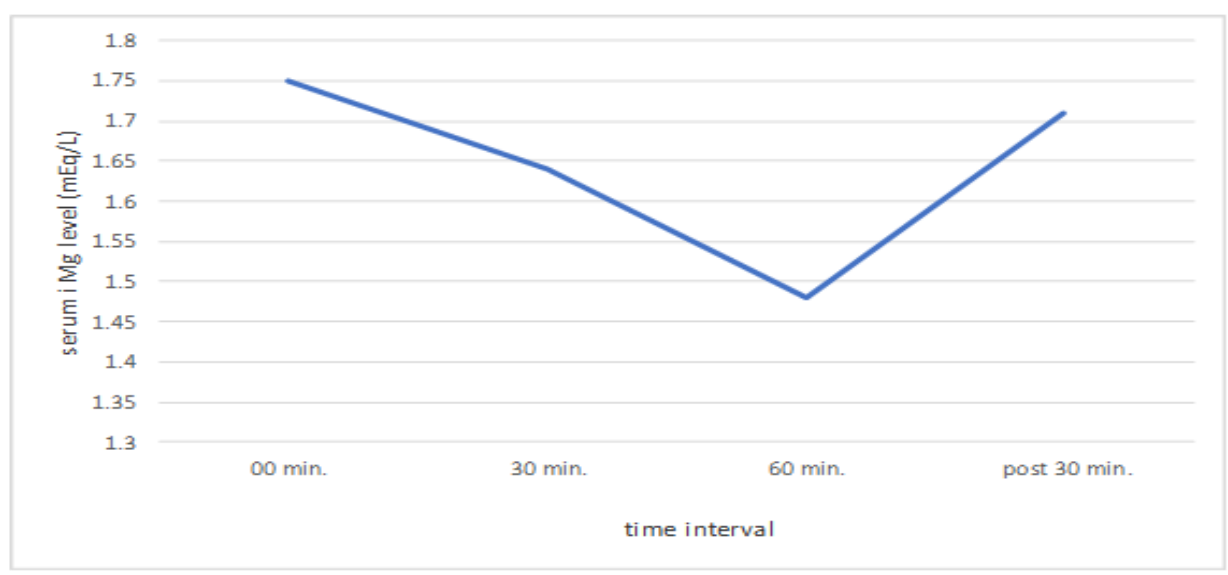

Fig. 4: Mean values of serum ionized magnesium (iMg) level in donors at different time intervals of apheresis procedure.

Assessment of PTH $(\mathrm{pg} / \mathrm{ml})$ revealed a significant increase during the procedure when compared with baseline value $(\mathrm{p}<0.05)$. The highest increase in PTH level was detected at $60 \mathrm{~min}$. then started to decrease again after the procedure but, didn't reach the baseline value as measured at $30 \mathrm{~min}$. post procedure (Table 4 \& Fig. 5).

Table (4): Statistical Comparison regarding mean values of parathyroid hormone (PTH) level $(\mathrm{pg} / \mathrm{ml})$ in first-time donors at different time intervals of apheresis procedure using ANOVA and LSD tests:

\begin{tabular}{|c|c|c|c|c|c|c|}
\hline \multirow{2}{*}{} & \multicolumn{4}{|c|}{ Time of sampling } & \multicolumn{2}{c|}{ ANOVA test } \\
\cline { 2 - 7 } & $\begin{array}{c}\text { 00 min. } \\
\text { (Baseline) }\end{array}$ & $\begin{array}{c}\text { At min. 30 of } \\
\text { procedure }\end{array}$ & $\begin{array}{c}\text { At min. 60 of } \\
\text { procedure }\end{array}$ & $\begin{array}{c}30 \text { min. post } \\
\text { procedure }\end{array}$ & F & P \\
\hline PTH $(\mathrm{pg} / \mathrm{ml})$ & $20.87 \pm 4.21$ & $28.87 \pm 6.23^{\mathrm{a}}$ & $36.61 \pm 5.92^{\mathrm{a}, \mathrm{b}}$ & $27.93 \pm 4.86^{\mathrm{a}, \mathrm{c}}$ & 108.01 & $0.000^{* *}$ \\
\hline
\end{tabular}

$$
\text { F: ANOVA } \quad * * \text { : Significant: } \mathrm{p}<0.05 \quad \text { min: minute }
$$


LSD for repeated measure ANOVA expressed as letters: a: Significant with (pre-procedure (baseline), b Significant with (at min. 30 of procedure) and c: Significant with (at min. 60 of procedure).

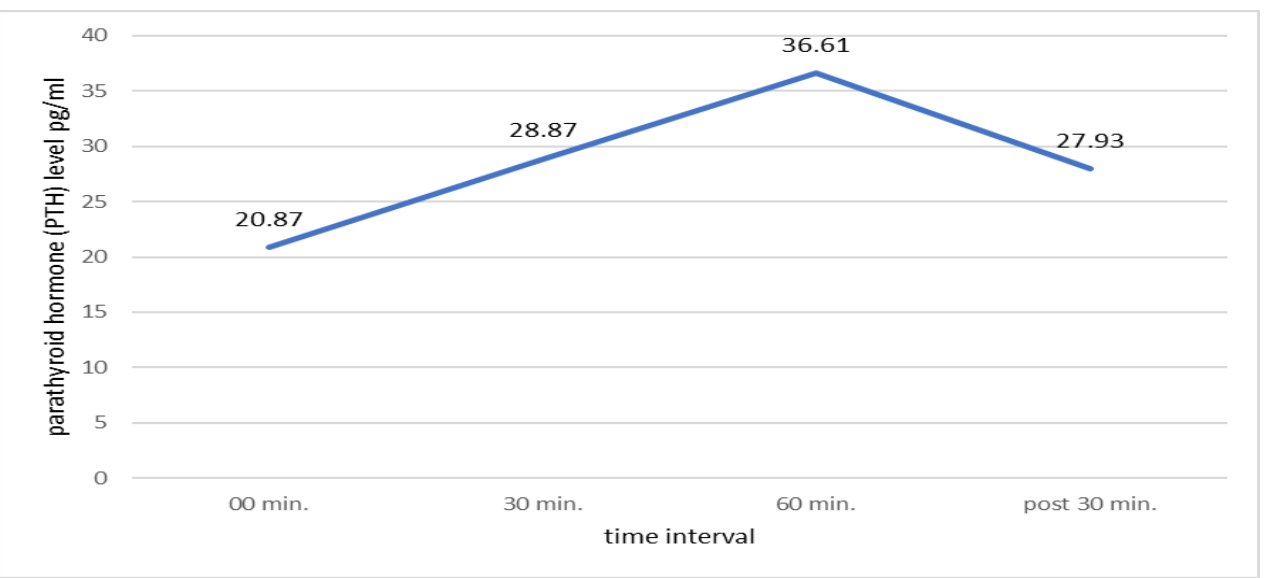

Fig. (5): Mean values of parathyroid hormone (PTH) level (pg/ml) at different time intervals of apheresis procedure.

Erythrocytes Phosphofructokinase activity showed a significant decrease during the procedure when compared with baseline activity $(\mathrm{p}<0.05)$, then the activity of the enzyme started to increase again after the procedure but didn't regain its baseline activity. Also, a significant difference was found between activity measured $30 \mathrm{~min}$. post procedure and that measured as baseline value $(\mathrm{p}<0.05)$ (Table 5, Fig. 6).

Table (5): Statistical comparison regarding mean values of erythrocytes phosphofructokinase activity (PFK) in first-time donors at different time intervals of apheresis procedure using ANOVA and LSD tests:

\begin{tabular}{|c|c|c|c|c|c|c|}
\hline & \multicolumn{4}{|c|}{ Time of sampling } & \multicolumn{2}{|c|}{ ANOVA test } \\
\hline & 00 min.(Baseline) & $\begin{array}{l}\text { at min. } 30 \text { of } \\
\text { procedure }\end{array}$ & $\begin{array}{l}\text { at min. } 60 \text { of } \\
\text { procedure }\end{array}$ & $\begin{array}{l}30 \text { min. post } \\
\text { procedure }\end{array}$ & $\mathrm{F}$ & $\mathrm{P}$ \\
\hline $\begin{array}{l}\text { Erythrocyte } \\
\text { PFK activity } \\
\text { (nmole/min/uni } \\
\begin{array}{c}t \text { number of } \\
\text { RBCs) }\end{array}\end{array}$ & $0.698 \pm 0.028$ & $0.684 \pm 0.015^{\mathrm{a}}$ & $0.652 \pm 0.031^{\mathrm{a}, \mathrm{b}}$ & $0.672 \pm 0.023^{\mathrm{a}, \mathrm{b}, \mathrm{c}}$ & 45.58 & $0.000 * *$ \\
\hline
\end{tabular}




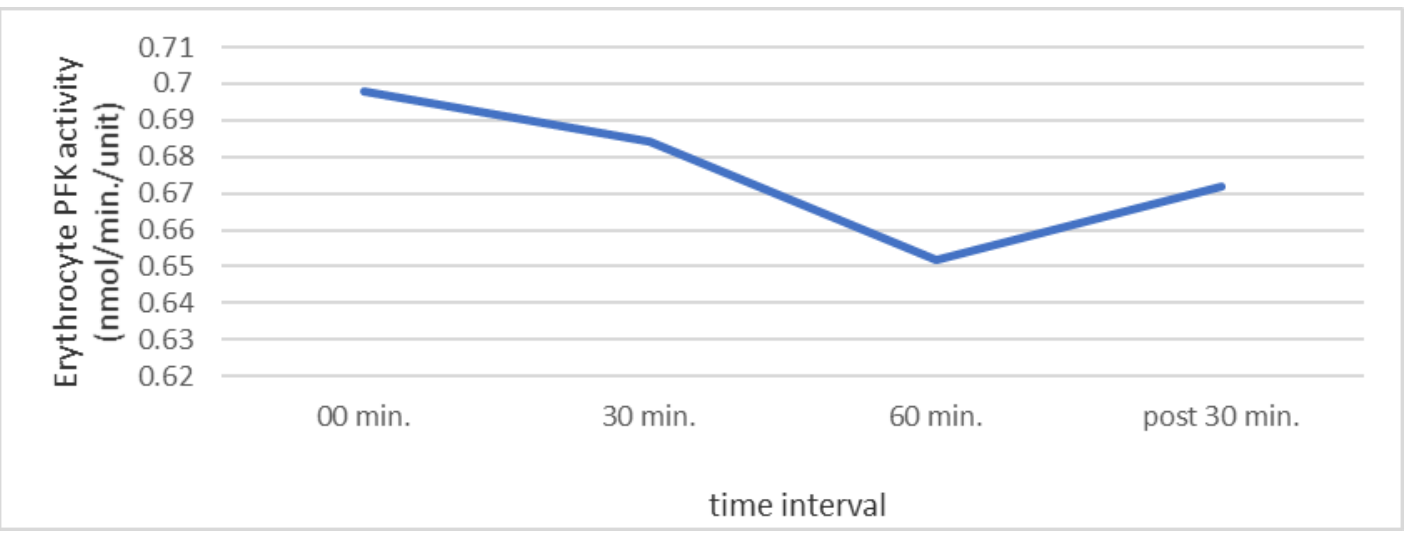

Fig. (6): Mean values of erythrocytes phosphofructokinase activity (PFK) at different time intervals of apheresis procedure.

When hematological parameters were assessed in apheresis donors, Only RBCs showed a significant decrease at 60 min. of the procedure and at $30 \mathrm{~min}$. post apheresis when compared with baseline value $(\mathrm{p}<0.05)$ (Table 6). On the other hand, no significant changes were found when $\mathrm{Hb}$ level $(\mathrm{g} / \mathrm{dl})$ or $\mathrm{Hct} \%$ were compared at the different time intervals of the procedure ( $>>0.05)$ (Table 6).

Table (6): Statistical comparison regarding mean values of hematological parameters in first time donors at different time intervals of apheresis procedure ANOVA and LSD tests

\begin{tabular}{|l|l|l|l|l|l|l|}
\hline \multirow{2}{*}{$\begin{array}{l}\text { Hematological } \\
\text { parameters }\end{array}$} & $\begin{array}{l}0.00 \quad \min \\
\text { (Baseline) }\end{array}$ & $\begin{array}{l}\text { min. 30 of } \\
\text { procedure }\end{array}$ & $\begin{array}{l}\text { min. 60 of } \\
\text { procedure }\end{array}$ & $\begin{array}{l}30 \quad \text { min. post } \\
\text { procedure }\end{array}$ & F & P \\
\hline RBC (million/ul) & $5.01 \pm 0.14$ & $4.96 \pm 0.71$ & $4.11 \pm 0.34^{\mathrm{a}}$ & $4.15 \pm 0.52^{\mathrm{a}}$ & 80.6 & $0.000^{* *}$ \\
\hline $\mathrm{Hb}(\mathrm{g} / \mathrm{dl})$ & $12.25 \pm 0.62$ & $12.18 \pm 0.73$ & $12.15 \pm 0.66$ & $12.17 \pm 0.68$ & 0.31 & 0.82 \\
\hline $\mathrm{Hct}(\%)$ & $38.48 \pm 0.71$ & $38.37 \pm 0.59$ & $38.34 \pm 0.67$ & $38.24 \pm 0.91$ & 1.4 & 0.25 \\
\hline
\end{tabular}

F: ANOVA $* *$ : Significant: $\mathrm{p}<0.05$ min: minute. LSD for repeated measure ANOVA expressed as letters: a: Significant with (pre-procedure (baseline), b Significant with (at min. 30 of procedure) and c: Significant with (at min. 60 of procedure).

\section{DISCUSSION}

Apheresis is a procedure used for collecting specific blood components by using a needle inserted in arm vein which pass through an extracorporeal circuit machine to separate the component desired. The separated component is removed and the remainder is returned to the donor by the same needle or via a needle in the other arm. Acid citrate dextrose (ACD) is added to the machine to prevent coagulation of blood. The returned blood to the donor hence contain citrate (Crookston and Novak, 2010). The aim of this study was to evaluate the possible toxic effects of citrate in apheresis donors for the first time.

Clinical evaluation of the donors enrolled in the study revealed that the most reported symptoms were lightheadedness, nausea, vomiting and shivering followed by 
twitches \&tremors. Tetany complicated $5.3 \%$ of the donors while no one of the donors developed seizures.

These results coincide with that of Bolan et al. (2001) who detected fall in ca level by about 33\% which resulted in an increase of nerve excitability with subsequent paresthesia, shivering, lightheadedness, twitching, and tremors. They stated that some donors developed nausea and vomiting and with cases of more ca decrease, the symptoms progressed to carpopedal spasm, tetany, and seizure.

Moreover, Bell et al. (2007) reported a case of severe citrate toxicity during first time platelet apheresis in a 40-year-old female donor with past medical history of hypertension, hyperlipidemia, reported medications included bumetanide, pravastatin. Thirty minutes from the start of the procedure, the donor developed tingling around the mouth, hands, and feet followed by severe facial and extremity tetany. They attributed these manifestations to citrateinduced hypocalcemia which was aggravated by bumetanide; a loop diuretic that may cause significant hypocalcemia.

When vital signs were assessed among donors, tachycardia and decrease of diastolic blood pressure were recorded during the procedure, but returned to normal when evaluated $30 \mathrm{~min}$. after apheresis.

Toyoshima et al. (2006) explained hypotension following infusion of citrate at a rate $>1.0 \mathrm{mmol} / \mathrm{kg} / \mathrm{h}$ by hypocalcemia which is more severe with increased infusion rate of citrate. Tachycardia also reported in such cases and is believed to be a reflex for hypotension.

The results of the study revealed not significant elevation in both bicarbonate level and partial pressure of $\mathrm{CO} 2$ (PCO2) when assessed during apheresis procedure.
These findings are explained by Kramer et al. (2003) who mentioned that exogenous citrate is metabolized by mitochondria of renal, hepatic and skeletal tissues which result in consumption of three hydrogen ions and release of three bicarbonate molecules per one citrate molecule causing blood alkalinity.

In addition, Callan et al. (2008) stated that metabolic alkalosis has complicated massive blood transfusion due to conversion of excess citrate into bicarbonate citrate intoxication as a result of citrate metabolism in the liver where it is converted into bicarbonate. Also, Bicakci and Olcay (2014) investigated metabolic changes due to citrate in patients who received blood transfusion and demonstrated metabolic alkalosis and respiratory acidosis as a result of citrate metabolism.

Absence of metabolic abnormalities in apheresis in contrary to that developed in massive blood transfusion can be explained by more citrate in stored blood ( $3 \mathrm{~g} / \mathrm{unit}$ of RBC) used for transfusion. Karina et al. (2014) mentioned that liver can metabolize up to $3 \mathrm{gm}$ of citrate in 5 minutes and infusion rates more than 1 unit of $\mathrm{RBC} / 5 \mathrm{~min}$ can result in metabolic alkalosis.

In consistent with these results, Kai \&Yuan (2015) stated that metabolic alkalosis is reported as a well-known hazard of massive blood transfusion, but it is not stated as a complication of non-massive blood transfusions.

A significant decrease of ica level was detected at $30 \& 60 \mathrm{~min}$. of apheresis with iMg level significantly decreased at 60 min. of the procedure. Then the levels returned again to normal level where non- 
significant differences were found between pre and post procedure values.

These results coincide with that of Kai and Yuan (2015) who stated that the anticoagulant effect of citrate is mediated through reversible chelation of divalent cations including calcium and magnesium affecting their normal physiologic functions. Also, Walter et al. (2016) mentioned that ACD disrupt coagulation by chelating calcium ions in the blood forming calciumcitrate complex with resultant hypocalcemia.

Also, Bolan et al. (2001) stated that infusion rate of citrate during plateletpheresis is adjusted so that metabolism, redistribution and short period of apheresis procedure prevent accumulation of citrate to toxic level. In cases of longer procedure duration or increased rate of infusion, citrate accumulation in blood will overwhelm its metabolism resulting in marked decrease in calcium and magnesium levels and this may explain development of citrate toxicity in some donors during apheresis.

Joseph et al. (2013) and Bialkowski et al. (2016) declared that during apheresis, citrate is infused at a rate higher than its removal to permit short runs. They added that although donors can generally tolerate up to $20 \%$ decrease in ca level, rapid infusion can be associated with citrate toxicity in the form of hypocalcemia with neuromuscular excitability or even seizures. In consistent with this, Humpe et al. (2000) Stated that ACD infusion rates of $0.8,1.0$ and $1.2 \mathrm{ml}$ ACD-A $/ \mathrm{min} / \mathrm{L}$ were accompanied by declines in calcium levels by $10-15 \%, \quad 15-25 \%$ and $20-35 \%$ respectively.

Sigler et al. (2018) conducted a study on 206 patient underwent 1176 therapeutic plasma exchange procedures in which ACD formula A (ACD-A) was used for anticoagulation together with iv calcium replacement. Despite uses of prophylactic iv calcium, patients developed hypocalcemia in 63 out of the 1176 procedures performed.

Parathyroid hormone was increased during apheresis when compared to preprocedure value and decreased again after the procedure but still a significant difference was found between $30 \mathrm{~min}$. post procedure and pre-procedure measurements.

These findings are in consistent with that of Bolan et al. (2003) and Muhammad et al. (2016) who stated that increase in PTH is short-lived reaching its maximum at the end of apheresis procedure, then start to decline again to reach nearly the baseline as early as 30 minutes after termination of citrate infusion. Hebert et al. (1997) explained increase in PTH in apheresis donors by sensitization of G-protein coupled receptors on surface of parathyroid gland and kidney upon decline in blood ca concentration with subsequent stimulation of secretory cells to release PTH.

On the other hand, a study carried out by Amrein et al. (2010) demonstrated elevation of PTH level up to one day after the procedure.

Chen Y. et al. (2009) compared the effects of citrate infusion and saline infusion on bone markers in 10 male plateletpheresis who were divided into 2 groups. Samples were collected at the beginning, in the middle and at the end of apheresis process and found that citrate infusion was accompanied by a significant increase of PTH together with decreased ca level when compared with saline infusion. Chu et al. (2010) explained that by the essential role of $\mathrm{PTH}$ in regulating serum calcium, so any change in ca level will affect PTH. 
Assessment of erythrocytes PFK activity revealed a significant decrease during procedure intervals when compared with pre-procedure value and although the enzyme activity started to increase again after apheresis, but it didn't reach the baseline activity, with a significant difference found when comparing activity measured $30 \mathrm{~min}$. post procedure and that measured pre-procedure. When hematological parameters were evaluated, a decrease in RBCs but not in $\mathrm{Hb}$ level or hematocrit $\%$ was detected.

Sola et al. (1994) who stated that citrate has an inhibitory effect on PFK. Michael and Harold (2012) mentioned that genetic deficiency of erythrocyte PFK is associated with hemolysis and reticulocytosis.

These findings are also supported by that of Mlakar and Legis (2006) \& Ros and Schulze (2013) who stated that citrate play a role in suppression of the enzyme activity.

Aleksandra and Matic (2010) Suggested interaction of citrate with a citrate allosteric site on PFK although this has not been studied on a sub molecular level.

\section{CONCLUSION}

Exposure of plateletpheresis firsttime donors to citrate may cause citrate toxicity manifested clinically by light headedness, nausea, vomiting, tremors, twitches, tetany, tachycardia and hypotension with alteration of biochemical parameters in the form of decreased calcium \& magnesium levels, increased PTH, decreased erythrocyte PFK activity with subsequent decreased RBCs integrity and possible hemolysis.

\section{RECOMMENDATIONS}

From the previous results, the following are recommended:
1-Readiness for managing possible serious reactions including severe hypocalcemia, hypomagnesemia associated with tetany, seizures and hemodynamic instability with establishing a plan to manage any complications during blood donation.

2-Perform pre-procedure assessment of serum calcium and magnesium levels together with evaluation of possible hemolysis after apheresis to identify cases requiring heightened cautions.

3-Further studies are recommended to study a safe alternative for acid citrate dextrose as an anticoagulant in plateletpheresis procedure.

\section{ACKNOWLEDGEMENT}

Great gratefulness and many thanks to the donors and medical stuff who provided a great support for this study to be accomplished.

\section{REFERENCES}

Aleksandra, U. and Matic, L. (2010): Evolution of Allosteric Citrate Binding Sites on 6-phosphofructo-1-kinase. Plos One, 5(11): e15447.

Amrein, K.; Katschnig, C.; Sipurzynski, S., Stojakovic, T.; Lanzer, G.; Stach, E. et al. (2010): Apheresis affects bone and mineral metabolism. Bone, 46:789-95.

Aniket, $\quad$ V. $\quad$ M.; Sunita, S. B.; Mahabaleshwar, V. H.; and Surendra, S. K. (2016): Altered erythrocyte glycolytic enzyme activities in type-II diabetes. Indian Journal of Clinical Biochemistry, 31(3): 321-325.

Bell, AM.; Nolen, JD.; Knudson, CM. and Raife, TJ. (2007): Severe citrate toxicity complicating volunteer apheresis platelet 
donation. Journal of Clinical Apheresis, 22(1):15-16.

Bialkowski, W.; Bruhn, R. E. and Papanek, P. (2016): Citrate anticoagulation: Are blood donors donating bone? Journal of Clinical Apheresis.,31(5):459-63.

Bicakci, Z and Olcay, L. (2014): Citrate metabolism and its complications in nonmassive blood transfusions: association with decompensated metabolic alkalosis+respiratory acidosis and serum electrolyte levels. Transfusion Apheresis Science. ,50(3):418-26.

Bolan, CD.; Cecco, SA.; Yau, YY.; Wesley, RA,; Oblitas, JM; Rehak, NN and Leitman SF (2003): Randomized placebo-controlled study of oral calcium carbonate supplementation in plateletpheresis: II. Metabolic effects. Transfusion, 43:1414-22.

Bolan, CD.; Greer, SE.; Cecco, SA.; Oblitas, JM.; Rehak, NN. And Leitman SF. (2001): Comprehensive analysis of citrate effects during plateletpheresis in normal donors. Transfusion ;41:1165-71.

Burgstaler, EA. (2006): Blood component collection by apheresis. Journal of Clinical Apheresis, 21:142-51.

Buchta, C.; Macher, M.; Bieglmayer, C.; Hocker, P. And Dettke, M. (2003): Reduction of adverse citrate reactions during autologous large-volume PBPC apheresis by continuous infusion of calciumgluconate. Transfusion, 43:1615-21.

Callan, MB.; Appleman, EH.; Shofer, FS.; Mason, NJ.; Brainard, BM.; Groman, RP. (2008): Clinical and clinicopathologic effects of plateletpheresis on healthy donor dogs. Transfusion, 48(10):2214-21.

Chen, Y.; Bieglmayer, C.; Hocker, P. and Dettke, M. (2009): Effect of acute citrate load on markers of bone metabolism in healthy volunteers. The international journal of transfusion medicine: Vox Sanguinis,97 (4): 324-329.

Chu, X.L.; Hou, J.M.; Lin, H., Zeng, J.; Chen, GL.; Chen, C.; Lin, J.; Chen, Y. (2010): Short-term effects of citrate on markers of bone metabolism in Chinese blood donor volunteers. Zhongguo Shi Yan Xue Ye Xue Za Zhi., 18:785-89.

Crookston, KP. and Novak, DJ. (2010): Physiology of Apheresis. In: McLeod, BC.; Szczepiorkowski, ZM.; Weinstein, R.; Winters, JL., editors. Apheresis: Principles and Practice. Bethesda, MD: AABB Press, pp. 45-69.

Custer, B.; Rios, JA.; Schlumpf, K., Kakaiya, RM.; Gottschall, JL.; Wright, DJ. et al. (2012): Adverse reactions and other factors that impact subsequent blood donation visits. Transfusion, 52 (1):118-26.

Hebert, S. C. ; Brown, E. M. and Harris, H.W. (1997): Role of the $\mathrm{Ca}(2+)$-sensing receptor in divalent mineral ion homeostasis. Journal of Experimental Biology , 200(pt 2):295-302.

Humpe, A.; Riggert, J.; Munzel, U. and Kohler, M. (2000): A prospective, randomized, sequential crossover trial of large-volume versus normal-volume leukapheresis procedures: effects on serum electrolytes, platelet counts, and other coagulation measures. Transfusion ,40: 36874.

Joseph, Ph., Ravi S. S. and Amardeep P. (2013): Adverse events associated with apheresis procedures: Incidence and relative frequency. Asian Journal of Transfusion Science, 7(1): 37-41.

Kai, Li and Yuan, Xu. (2015): Citrate metabolism in blood transfusions and its relationship due to metabolic alkalosis and respiratory acidosis. International Journal of 
Clinical and Experimental Medicine , 8(4):6578-84.

Karina, R.; Maria, V; Gabriela, C and Graciela, Z. (2014): Hypocalcemia, Hyperkalemia and massive hemorrhage in liver transplantation. Colombian Journal of Anesthesiology, 42(3): 214-19.

Kramer, L.; Bauer, E.; Joukhadar, C.; Strobl, W.; Gendo, A.; Madl, C. and Gangl A. (2003): Citrate pharmacokinetics and metabolism in cirrhotic and noncirrhotic critically ill patients. Critical Care Medicine, 31(10):2450-55.

Lee, G and Arepally, GM. (2012): Anticoagulation techniques in apheresis: from heparin to citrate and beyond. Journal of Clinical Apheresis, 27(3):117-25.

Mariano, M. (2017): Apheresis Techniques. Giornale Italiano di Nefrologia.,34(5):7388.

Michael, W. and Harold, T. (2012): The complete blood count, bone marrow examination and blood banking: general comments and selected techniques. In : Small animal clinical diagnosis by laboratory methods. 5th edition, Saunders, pp:1-448.

Mlakar, T. and Legisa, M. (2006): Citrate inhibition-resistant form of 6phosphofructo- 1-kinase from Aspergillus niger. Applied and Enviromental Microbiology, 1 (72): 4515-21.

Monika, M. and Tarun, J. (2014): Complications associated with blood donations in a blood bank at an Indian tertiary care hospital. Journal of Clinical and Diagnostic Research., 8(9): JC05-JC08.

Mor, 1.; Cheung, E. C. and Vousden, K. H. (2011): Control of glycolysis through regulation of PFK1: Old friends and recent Additions. Cold Spring Harbor Symposia on Quantitative Biology. 76: 211-16.
Muhammad, N.F.; Abdul, R. H.; Aishah, K. A.;Noor, H. M.; Noor, Z. I.; Nor, H. R. et al. (2016): The alteration of parathyroid hormone level in Plateletpheresis donors. Journal of Scientific Research and Development 3 (2): 76-86.

Ros, S. and Schulze, A. (2013): Balancing glycolytic flux: the role of 6-phosphofructo2-kinase/fructose 2,6-bisphosphatases in cancer metabolism. Cancer\& Metabolism ,1(1):8.

Samuel, O.; Thomas, N.; Ernest, O.; Imelda, $\mathrm{N}$; Elvis, N. and Ifeyinwa, Ezema. (2010): Comparison of haematological parameters determined by the Sysmex KX - 2IN automated haematology analyzer and the manual counts. BMC Clinical Pathology, 10: 3 .

Sigler, K.; Lee, J. and Srivaths, P. (2018): Regional citrate anticoagulation with calcium replacement in pediatric apheresis. Journal of Clinical Apheresis, 33(3):27477.

Sola, M.M.; Oliver, F.J.; Salto, R.; Gutiérrez, M. and Vargas, A. (1994): Citrate inhibition of rat-kidney cortex phosphofructokinase. Molecular and Cellular Biochemistry. ,135(2):123-8.

Swarup, D.; Dhot, P. S. and Arora, S. (2009): Study of Single Donor Platelet (SDP) Preparation by Baxter CS 3000 plus and Haemonetics MCS plus. Medical journal, Armed Forces India, 65(2), 137140.

Szczepiorkowski, Z. M.; Winters, J. L.; Bandarenko, N.; Kim, H. C.; Linenberger, M. L.; Marques, M. B. et al. (2010): Guidelines on the use of therapeutic apheresis in clinical practice - Evidencebased approach from the apheresis applications committee of the American Society for Apheresis. Journal of Clinical Apheresis. 25 (3): 83-177. 
Toyoshima, S.; Fukuda, T; Masumi, S.; Nakashima, Y.; Kawaguchi, Y.; Nakayama, M. (2006): Maximum acceptable infusion rate of citrate: relationship between blood ionized calcium levels and cardiovascular effects in anesthetized rats. Clinical Nutrition , 25(4):653-60.

Van Wijk. R. and Van Solinge. W. (2005): The energy-less red blood cell is lost: erythrocyte enzyme abnormalities of glycolysis. Blood, 106(13):4034-42.

Walter, B; Roberta, B.; Gustaf, E. and Paula, R. (2016): Citrate anticoagulation : are blood donors donating bone ?. Journal of Clinical Apheresis,31(5):459-63.

Wu, C., Khan, S.A.; Peng, L.J. and Lange, A.J.(2006): Roles for fructose-2,6bisphosphate in the control of fuel metabolism: beyond its allosteric effects on glycolytic and gluconeogenic enzymes. Advances in Enzyme Regulation, 46 (1):72-88.
Zheng, R.; Zhao, Y.; Wu, J.; Wang, Y.; Liu, J.; Zhou, Z.; et al. (2018): A novel PNPLA6 compound heterozygous mutation identified in a Chinese patient with Boucher-Neuhauser syndrome. Molecular Medicine Reports.18(1):261-267.

Zoppi, F.; De Gasperi, A.; Guagnellini, E.; Marocchi, A.; Mineo, E.; Pazzucconi F, et al. (1996): Measurement of ionized magnesium with AVL 988/4 electrolyte analyzer: preliminary analytical and clinical results. Scandinavian Journal of Clinical and Laboratory Investigation Supplementum., 224:259-74. 
تأثير حمض الاكستروز سيترات أثناء عملية فصل الصفائح الدموية على المتبرعين الأصحاء لاول مرة : ما بين السلامة و التسمم التصومة

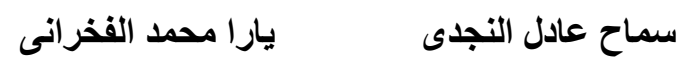

قسم الطب الثرعى و السموم الاكلينيكية _كلية الطب البشرى- جامعة الزقازيق

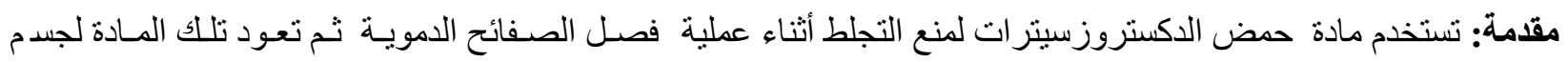

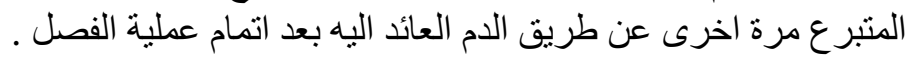

الهذف من البحث: هو تقييم التاثير السمى لمادة حمض الدكستروزسيترات فى المتبر عينالاصحاء لاول مرة عن طريدق التقبيم الاكلينيكى و المعملى.

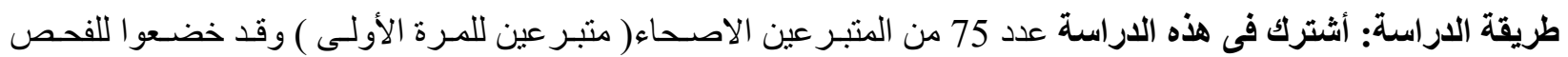

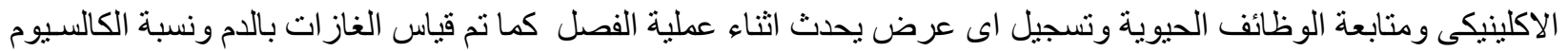

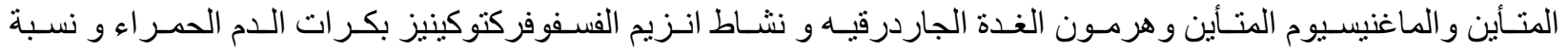

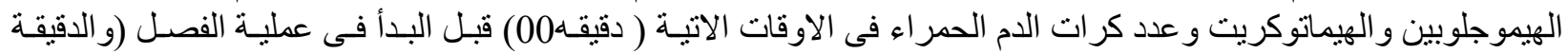

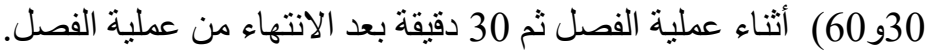

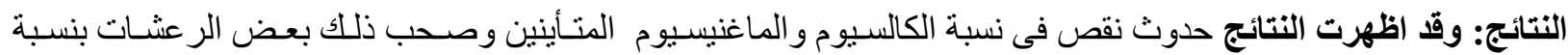

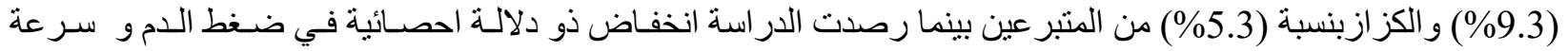

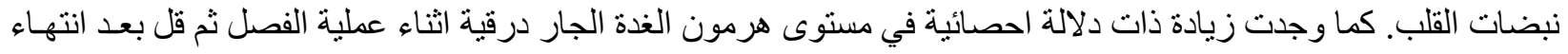

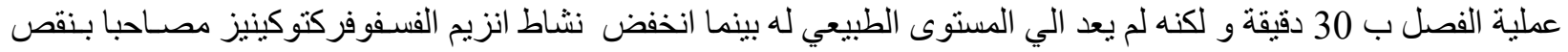

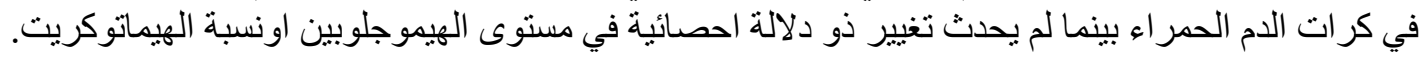

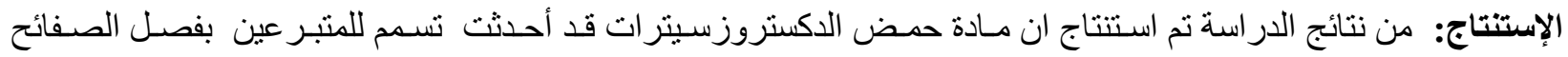

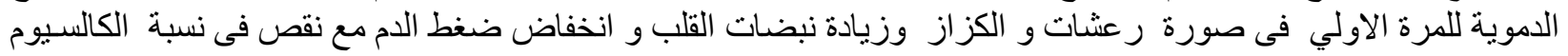

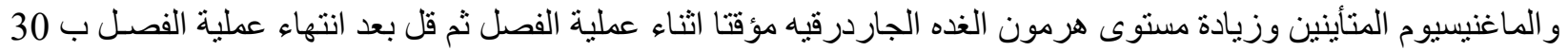

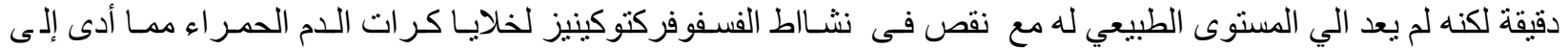
ضعفها و سهولة تكسير ها.

التوصيات: الاستعداد للتعامل مع المخاطر المحتملة من نقص حساد في مسـتوى الكالسـيوم و الماغنسـيوم في الـم و والمـرتبطين

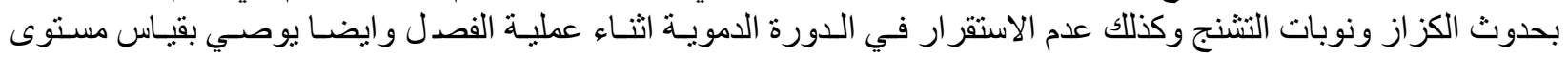

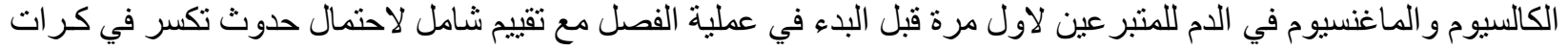
الدم الحمر اء بعد عملية الفصل. 